\title{
The Role of Commercial Banks in Providing Agricultural Credit in Tamil Nadu (Extent and Factors Influencing Investment) - India: A View
}

\section{Selvaraj $\mathbf{N}^{*}$ and Balajikumar $\mathbf{P}$}

Saraswathi Narayanan College, Madurai, Tamilnadu, India

\begin{abstract}
Agriculture plays a crucial role in the development of the Indian economy. It accounts for about 19 per cent of GDP and about two-thirds of the population is dependent on the sector. The Approach Paper to the Eleventh Five Year Plan has set a target of 4 per cent for the agriculture sector within the overall GDP growth target of 9 per cent. Capital investment in agriculture was made by farmers in various forms, such as farm lands, bunding and other land improvements including land reclamation, farm equipment, farm buildings, livestock, irrigation, poultry, storage arrangements and transport equipment. An attempt has been made in this paper to find out the extent of capital investment in agriculture made by the sample farmers and the factors that had influenced the capital investment in agriculture. Capital investment in agriculture made by farmers and the level of capital investment made were measured with the help of a scale constructed with the help of ten selected components. The number of farmers and the level of capital investment made by them are found to be more in the case of those who had reported a medium level of investment, followed by the number of farmers who had reported a low level of investment and those who had reported a high level of investment. The personal factors influencing the level of capital investment in agriculture, namely, educational qualifications and the size of family had a role to play in establishing the level of capital investment in agriculture. The other personal factors of farmers such as their experience in farming, use of communication media and their participation in training programmes had also a lot to do with the level of capital investment. Agriculture in India, viewed as a way of life, was not considered a productive proposition by the socially, economically and technologically backward population. The inter-sectoral mobility of personnel, resources and technology was very limited and it had created a vicious circle of technological isolation in the agricultural sector
\end{abstract}

Keywords: Agricultural sector; Chi-square test; Capital investment; Farmers

\section{Introduction}

Agriculture plays a crucial role in the development of the Indian economy. It accounts for about 19 per cent of GDP and about twothirds of the population is dependent on the sector. The importance of farm credit as a critical input to agriculture is reinforced by the unique role of Indian agriculture in the macro economic framework and its role in poverty alleviation. Recognizing the importance of agriculture sector in India's development, the Government and the Reserve Bank of India (RBI) have played a vital role in creating a broad-based institutional framework for catering to the increasing credit requirements of the sector. Agricultural policies in India have been reviewed from time to time to maintain pace with the changing requirements of the agriculture sector, which is an important segment of the priority sector lending of scheduled commercial banks (SCBs) and a target of 18 per cent of net bank credit has been stipulated for the sector. The Approach Paper to the Eleventh Five Year Plan has set a target of 4 per cent for the agriculture sector within the overall GDP growth target of 9 per cent. In this context, the need for affordable, sufficient and timely supply of institutional credit to agriculture has assumed critical importance [1-3].

The evolution of institutional credit to agriculture could be broadly classified into four distinct phases-1904-1969 (predominance of co-operatives and setting up of RBI), 1969-1975 (nationalization of commercial banks and setting up of Regional Rural Banks (RRBs), 1975-1990 (setting up of NABARD) and from 1991 onwards (financial sector reforms).

The genesis of institutional involvement in the sphere of agricultural credit could be traced back to the enactment of the Cooperative Societies Act in 1904. The establishment of the RBI in 1935 reinforced the process of institutional development for agricultural credit. The RBI is perhaps the first central bank in the world to have taken interest in the matters related to agriculture and agricultural credit, and it continues to do so

Capital investment in agriculture was made by farmers in various forms, such as farm lands, bunding and other land improvements including land reclamation, farm equipment, farm buildings, livestock, irrigation, poultry, storage arrangements and transport equipment. The level of capital investment in agriculture varied from farmer to farmer, farm to farm, place to place and time to time.

An attempt has been made in this paper to find out the extent of capital investment in agriculture made by the sample farmers and the factors that had influenced the capital investment in agriculture. Further, an attempt has also been made to analyze the relationship between various factors and level and capital investment. It could be observed that both personal factors such as educational qualifications, size of the family, experience in farming, use of communication media and participation in training camps, and financial factors such as possession of own farm lands, possession of irrigation wells carrying on farming as a primary or as a secondary activity, the incomes of

*Corresponding author: Selvaraj, Assistant Professor of Commerce, Saraswath Narayanan College, Madurai 625022, Tamilnadu, India, Tel: 09843727975, E-mail: selvaraj_narayanan@yahoo.com

Received January 03, 2015; Accepted May 19, 2015; Published May 26, 2015

Citation: Selvaraj N, Balajikumar P (2015) The Role of Commercial Banks in Providing Agricultural Credit in Tamil Nadu (Extent and Factors Influencing Investment) - India: A View. Bus Eco J 6: 158. doi:10.4172/2151-6219.1000158

Copyright: $\odot 2015$ Selvaraj N, et al. This is an open-access article distributed under the terms of the Creative Commons Attribution License, which permits unrestricted use, distribution, and reproduction in any medium, provided the original author and source are credited. 
family members, utilisation of bank loans, offer of incentives for certain schemes and mechanization have all influenced the level of capital investment in agriculture.

\section{Analytical Framework}

Keeping in view the objectives of the study, the 600 sample beneficiaries were stratified into two categories, namely marginal and small farmers. Out of the 600 sample farmers, 232 sample farmers (38.67 per cent) and the remaining 368 sample farmers (61.33 per cent) are under the category of large and small farmer groups respectively. Further, the sample farmers were post stratified into non-defaulters and defaulters. Out of the 232 large farmers, 136 ( 58.52 per cent) belong to non-defaulter group and the remaining 96 (41.38 per cent) belong to defaulter group. In the small farmer group, out of 368 sample farmers, 156 (42.39 per cent) and 212 (35.33 per cent) belong to non-defaulter and defaulter groups respectively [4-6].

Capital investment in agriculture made by farmers and the level of capital investment made were measured with the help of a scale constructed with the help of ten selected components.

In order to examine the factors influencing capital investment in agriculture the chi-square test of the following form has been used:

$$
\chi^{2}=(\mathrm{O}-\mathrm{E})^{2} / \mathrm{E}
$$

where $\mathrm{O}=$ observed frequency

$\mathrm{E}=$ expected frequency

Degree of Freedom is $(\mathrm{r}-1)(\mathrm{c}-1)$

where, ' $r$ ' is the number of rows, and

' $c$ ' is the number of columns in the contingency table.

\section{Components of Investment in Agriculture}

In order to find out the extent of capital investment in agriculture, the following ten major components are identified.

a. Farm Lands

b. Bunding and other land improvements including land reclamation

c. Digging and repair of wells

d. Farm equipment, tools and machinery

e. Investments in mechanical power

f. Farm buildings and cattle sheds

g. Farm livestock

h. Farm Poultry

i. Development of other irrigation sources and

j. Transport and storage facilities

\section{Farm lands}

Investment in the purchase of land formed the most important outlet for the consumption of the savings of farmers. Buying of land resulted in an increase in the capital assets. Therefore, money spent in the purchase of land should be considered an investment in agriculture. The farmlands belong to the category of either wetlands or dry lands. The ownership of farmlands has a significant part to play in the selection of crops to be cultivated. Moreover the ownership of farmlands motivates the farmers to make increased investments in agriculture. Hence, the saying, 'The magic of ownership converts land into gold".

\section{Land improvement}

Expenditure on bonding, terracing, fencing, land improvements and land reclamation has to be incurred not only for the maintenance and repairs of land that is cultivated, but also for the prevention of soil erosion and for the preservation of soil facility. As these operations increase, the productivity of land also increases and fallow land is also brought under cultivation. Hence, expenditure incurred on such activities can be treated as capital investment.

\section{Digging and repair of wells}

Construction of a new well definitely forms part of capital investment. But in respect of wells which are already in use, expenditure is incurred for carrying out repairs, needed for maintaining the value of assets intact. In some cases, money is spent for deepening the wells, for broadening or strengthening their walls, and for preserving their usefulness. As the expenditure incurred on such items increases the utilization of the existing old wells they are considered as an addition to the existing capital assets and therefore, are classified as capital investment.

\section{Farm equipment tools and machinery}

The equipment used by farmers may either be ordinary implements such as ploughs, harrows, axes and the like which were used generally by most of the small farmers. Purchases of ordinary implements by farmers were usually in the nature of replacement of equipment for farm operations. Any addition made to the existing stock of farm equipment should be considered as capital investment. The possession of tools and implements helped the farmers either to carry out the jobs by themselves or through hired labour. Agricultural operations required investments in the form of tools and equipments to enable the full utilisation of those tools and equipments in agricultural operations for increased land productivity.

\section{Investment in mechanical power}

Equipment requiring mechanical or electric power were generally used by all the farmers through the medium and large-sized groups of farmers used these to a greater extent. The purchase of mechanical power equipment definitely added to the capital assets of farmers, and helped them to carry on their agricultural operations more efficiency and profitably.

\section{Investments in farm buildings and cattle sheds}

Expenditure on construction of farmhouses and cattle sheds resulted in increased capital assets of farmers, which should be treated as capital investment. Farm buildings included storage houses, cages, coops and ridges. Farm construction like storage houses helped to store the harvested produce immediately after harvest so that they may be sold at the highest possible prices at a later date [7-9].

\section{Farm livestock}

The farmers, whether they possessed farm lands of their own or not, considered livestock as their major source of income. Farm livestock enabled the farmers to reduce their cultivation expenses and increased their earnings. Livestock included all farm animals and dairy animals and also goats and sheep. A vast majority of agriculturalists owned farm and dairy cattle. In the study area the number of such livestocks owned 
varied from farmer to farmer depending on their economic condition.

\section{Farm poultry}

Poultry-keeping was a source of income for the farmers of the study area. As their feed was confined mainly to the farm rejects and kitchen wastages, their rearing did not involve much of an expenditure. They provided farmyard manure, which added to the fertility of the soil and to the income of the farmers which enabled greater investment in agriculture by the farmers [10-13].

\section{Development of other irrigations sources}

Expenditure on the development of irrigation sources, which either did not exist before or was not fully developed earlier, added to the production of crops from the land. Thus, the expenditure reported under this category is considered an addition to the capital assets of farmers.

\section{Transport and storage facilities}

Transport definitely added to the capital assets of the farmers and helped them to shift their produce from fields to their houses for storage and from villages to markets.

\section{The Capital Investment Scale}

Since there was no standard scale that was readily available for measuring the capital investment in agriculture, a scale, known as the 'capital investment scale' was constructed with the help of ten identified components of capital investment and a score of ten was assigned to each of the ten components. The following table is useful in this context.

It has been observed from the Table 1 that the components of capital investment scale and the scores assigned to each one of the ten components. The first component was identified as the farmland and a

\begin{tabular}{|l|l|c|}
\hline SI. No. & Component & Score \\
\hline 1. & Farm Land & 10 \\
\hline 2. & Land Improvement & 10 \\
\hline 3. & Digging and repair of wells & 10 \\
\hline 4. & Farm equipment, tools and machinery & 10 \\
\hline 5. & Investment in mechanical power & 10 \\
\hline 6. & Farm buildings, cattle sheds and the like & 10 \\
\hline 7. & Farm livestock & 10 \\
\hline 8. & Farm poultry & 10 \\
\hline 9. & Development of other irrigational sources & 10 \\
\hline 10. & Transport and storage facilities & 10 \\
\hline Total & & 100 \\
\hline
\end{tabular}

Table 1: Components of capital investment scale and the scores assigned to each one of the components.

\begin{tabular}{|l|l|c|}
\hline SI. No. & Component & Score \\
\hline 1. & Farm Land & 27 \\
\hline 2. & Land Improvement & 24 \\
\hline 3. & Digging and repair of wells & 15 \\
\hline 4. & Farm equipment, tools and machinery & 17 \\
\hline 5. & Investment in mechanical power & 14 \\
\hline 6. & Farm buildings, cattle sheds and the like & 20 \\
\hline 7. & Farm livestock & 21 \\
\hline 8. & Farm poultry & 14 \\
\hline 9. & Development of other irrigational sources & 16 \\
\hline 10. & Transport and storage facilities & 12 \\
\hline
\end{tabular}

Table 2: Highest geometric mean for each of the components of capital investment.

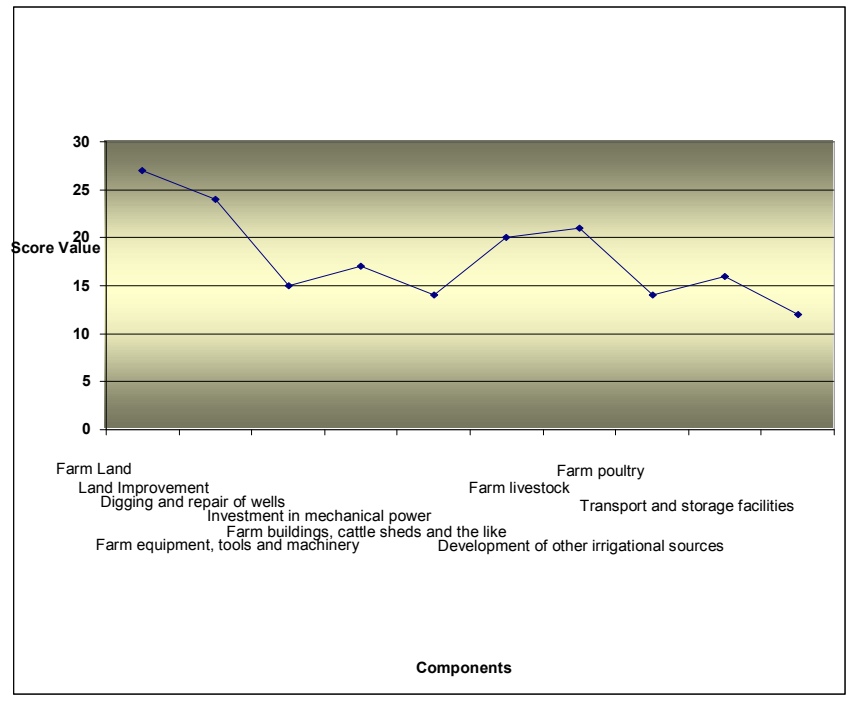

Figure 1: Highest geometric mean for each of the components of capital investment.

score of ten was assigned to it. The increase in the value of agricultural land was calculated, by assuming the previous year's value as 100 and the geometric mean for the growth for five years $(2008-09,2012-13)$ was calculated. The highest geometric mean was assigned ten scores.

It has been revealed from the Table 2 that the value of the calculated highest geometric mean for each of the ten components of capital investment. Based on these calculated values, the score for each of the ten components was calculated by dividing the total score for the component by the highest geometric mean of the components (Figure 1).

The distribution of the scores was worked out by considering the calculated geometric mean for the sample farmer, and multiplying it by the score for each of the components of capital investment.

In the area of farm lands, the highest geometric mean for the component was 27 . If the geometric mean for the sample farmers for the component 'farm lands' was assumed to be 12 , the score obtained by him was calculated as $10 / 27 \times 12=4.44$.

In the same way, the score values of farmers for the other components were obtained and the sum of all the scores of 10 components were taken into account for arriving at the total score value for that farmer. The total score value indicated the level of investment in agriculture by that farmer.

\section{Extent of capital investment}

The extent of capital investment in agriculture was measured by the scores obtained by the 300 sample farmers. Based on the scores obtained, farmers were classified into three categories namely, farmers who had made a low level of capital investment. Based on the scores obtained, farmers were classified into three categories, namely, farmers who had made a low level of capital investment, farmers who had made medium level of capital investment and farmers who had made a high level of capital investment. Table 3 presents the extent of capital investment made by the 300 sample farmers classified according to their level of investment. Farmers who had obtained a score of less than 34 were classified as farmers who had made a low level of investment while farmers who had obtained a score ranging from 34 to 67 were 


\begin{tabular}{|c|c|c|}
\hline SI. No. & Score of the Sample Farmers & Level of Capital Investment \\
\hline 1. & $1-33$ & Low \\
\hline 2. & $34-67$ & Medium \\
\hline 3. & $68-100$ & High \\
\hline
\end{tabular}

Source: Primary Data

Table 3: Classification of farmers according to their levels of capital investment

\begin{tabular}{|c|c|c|}
\hline SI. No. & Level of Investment in Agriculture & Number of Sample Farms \\
\hline 1. & Low Level & 156 \\
\hline 2. & Medium Level & 316 \\
\hline 3. & High Level & 128 \\
\hline All Levels & & 600 \\
\hline
\end{tabular}

\section{Source: Primary data}

Table 4: Classification of the sample farms according to levels of investment in agriculture.

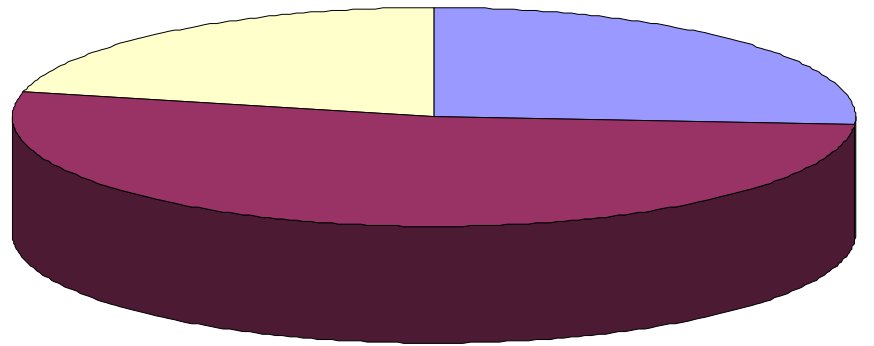

$\square$ Low Level $\square$ Medium Level $\square$ High Level

Figure 2: Classification of the sample farms according to levels of investment in agriculture.

classified as farmers who had made a medium level of investment, and those farmers who had obtained a score of more than 67 and upto 100 were classified as farmers who had made high level of capital investment. The words, 'farmers' and the 'sample farms' have been used interchangeably in this section as they do not make any difference in understanding this section

It has been inferred from Table 4 that out of a total of 600 sample farms, 156 were found to be in the category of low level of capital investment, 316 in the medium level of investment and 128 farms in the high level of investment in agriculture (Figure 2).

\section{Personal factors}

This section deals with personal factors which have influenced the farmers to prefer capital investment. Some important personal factors were identified in the study such as educational qualifications, size of the family, experience in farming, use of communication media and participation by the farmers in training camps.

In order to identify the influence of each one of these factors which made the farmers prefer a particular level of capital investment in agriculture, five null hypotheses were formed. They are:

a. The educational qualifications of farmers did not influence the level of capital investment

b. The size of family did not influence the level of capital investment

c. The experience in farming did not influence the level of capital investment

d. The use of the communication media did not influence the level of capital investment and

e. The participation in training campus did not influence the level of capital investment

Educational qualification: Education is considered to be an important factor which motivates and guides the farmers to perform their farming operations effectively and efficiently. The farming operations by themselves may not require any formal education. But the selection of seeds and crops, the application of manures and new techniques, the adoption of scientific methods in undertaking farming operations, the utilization of incentive schemes offered by the Government, efficient water management, maintenance of farm buildings and storage facilities, using market information, availing of loan facilities and analysing cost-benefit factors require education. The illiterate farmers depend upon others for such information. For this study, the educational qualifications of the heads of the sample families were grouped into two categories; as those who had studied upto VII standard and those who had studied above the level of VIII standard. This classification was made, as most of the sample villages were found to have middle schools and there was much concern among the parents of the area to admit their children only in the local schools. Since educational qualifications help motivate farmers to adopt improved farming techniques and practices, it is taken as an important factor influencing the level of capital investment in agriculture [14].

The classification of the heads of sample families according to their educational qualifications and the different levels of capital investments made by them in agriculture is shown in Table 5 .

Table 5 reveals that out of 600 sample farmers, 36 per cent or 216, of them had studied up to VII standard and 64 per cent or 384 of them had studied beyond VIII standard. Out of 156 farmers who had made a high level of investment, 126 of them ( 80.77 per cent) had qualifications above VIII standard and only 30 farmers ( 19.23 per cent) reported that they had studied upto VIII standard. Out of 316 farmers who were found to have made a medium level of investment, 246 of them (77.85 per cent) had qualification above VIII standard and only 70 farmers (22.15 per cent) had qualifications upto VIII standard. In the case of the low level of investment, out of 128 farmers, 116 of them had qualification upto VIII standard (90.63 per cent) and 12 of them (9.37 per cent) had studied beyond VIII standard.

Here, a null hypothesis was formulated, such as the educational qualifications and the level of capital investment which were two independent variables. To test the null hypothesis the chi-square test was applied and the results are presented in Table 6.

Since the calculated chi-square value is greater than that of the table value at 5 per cent level of significance, the null hypothesis is rejected.

\begin{tabular}{|l|c|c|c|c|}
\hline \multirow{2}{*}{ Educational Qualification } & \multicolumn{3}{|c|}{ Levels of Investment } & \multirow{2}{*}{ Total } \\
\cline { 2 - 4 } & High & Medium & Low & \\
\hline Up to VII standard & 30 & 70 & 116 & 216 \\
& $(19.23)$ & $(22.15)$ & $(90.63)$ & $(36.0)$ \\
\hline Above VII standard & 126 & 246 & 12 & 384 \\
& $(80.77)$ & $(77.85)$ & $(9.37)$ & $(64.0)$ \\
\hline All families & 156 & 316 & 128 & 600 \\
& $(100)$ & $(100)$ & $(100)$ & $(100)$ \\
\hline
\end{tabular}

Source: Primary data

Table 5: Classification of the sample farmers according to their educational qualifications and their levels of capital investment in agriculture. 


\begin{tabular}{|l|l|l|l|l|l|}
\hline $\begin{array}{l}\text { Groups } \\
\text { Compared }\end{array}$ & $\begin{array}{l}\text { Calculated } \\
\text { Value }\end{array}$ & $\begin{array}{l}\text { Table } \\
\text { Value }\end{array}$ & $\begin{array}{l}\text { Degrees of } \\
\text { Freedom }\end{array}$ & $\begin{array}{l}\text { Level of } \\
\text { Significance }\end{array}$ & Inference \\
\hline $\begin{array}{l}\text { Educational } \\
\text { qualifications and the } \\
\text { level of investment }\end{array}$ & 211.68 & 5.991 & 2 & 5 per cent & Significant \\
\hline
\end{tabular}

Table 6: Results of the chi-square test.

\begin{tabular}{|l|c|c|c|c|}
\hline \multirow{2}{*}{ Size of the Familyt } & \multicolumn{3}{|c|}{ Levels of Investment } & \multirow{2}{*}{ Total } \\
\cline { 2 - 4 } & High & Medium & Low & \\
\hline Small Family & 98 & 40 & 38 & 176 \\
& $(62.82)$ & $(12.66)$ & $(29.69)$ & $(29.33)$ \\
\hline Big Family & 58 & 276 & 90 & 424 \\
& $(37.18)$ & $(87.34)$ & $(70.31)$ & $(70.67)$ \\
\hline All Families & 156 & 316 & 128 & 600 \\
& $(100)$ & $(100)$ & $(100)$ & $(100)$ \\
\hline
\end{tabular}

\section{Source: Primary data}

Figures in brackets represent percentage to total.

Table 7: Classification of sample farmers according to size of the family and their levels of capital investment.

\begin{tabular}{|l|l|l|l|l|l|}
\hline $\begin{array}{l}\text { Groups } \\
\text { Compared }\end{array}$ & $\begin{array}{l}\text { Calculated } \\
\text { Value }\end{array}$ & $\begin{array}{l}\text { Table } \\
\text { Value }\end{array}$ & $\begin{array}{l}\text { Degrees of } \\
\text { Freedom }\end{array}$ & $\begin{array}{l}\text { Level of } \\
\text { Significance }\end{array}$ & Inference \\
\hline $\begin{array}{l}\text { Size of the family and } \\
\text { the level of Capital } \\
\text { investment }\end{array}$ & 128.82 & 5.991 & 2 & 5 per cent & Significant \\
\hline
\end{tabular}

Table 8: Results of the chi-square test.

Therefore the level of capital investment is dependent upon the educational qualifications of the farmer. Hence, there existed a close relationship between educational qualifications of farmers and the level of capital investment.

Size of the family: Size of the family is an important factor which deserves special consideration in the context of capital investment. Successful farming is the result of the joint activity of the family members, irrespective of their economic or professional status. The farming operations depend to a large extent on manual labour and the members of the families of farmers accustomed to it. For this study, the families were classified into small families and big families. A family having more than two children, besides the farmer and his wife, or families consisting of more than four members, in general, were considered big families and families having four members or less were classified as small families.

The relationship between the size of family and the level of capital investment is presented in Table 7.

From the Table 7 it has been inferred that out of 600 sample families of farmers, 176 (29.33 per cent) belonged to the small family group and 424 (70.67 per cent) belonged to the big family group. Out of 156 farmers who had a high level of capital investment, 98 belonged to small-sized families and 58 belonged to the big family category. Out of 316 farmers who had a medium level of investment, 276 belonged to the big family group and 40 of them belonged to the small family group. In the case of low-level investment in the farms, out of a total of 128 farmers, 90 belonged to the big family group and 38 belonged to the small family group [15].

A null hypothesis was formulated that the size of the family and the level of capital investment were two independent variables. To test the null hypothesis the chi-square test was applied and the results are presented in Table 8 .

It is clearly evident from Table 8 that the calculated chi-square value is greater than the Table value at 5 per cent level of significance; and hence the null hypothesis is rejected. It can be concluded that the level of capital investment is dependent upon the size of the family of farmers. Hence, there is a close relationship between the level of capital investment of farmers and their family size.

Experience in farming and the level of capital investment: Surplus farm income motivates the farmer to invest more in the form of farm assets to enable him to carry on agricultural operations efficiently and successfully. A farmer with a long period of experience in farming does the agricultural operations in a better manner than another who has relatively a less number of years of farming experience. Moreover, the farmers who are engaged in agriculture as their ancestral occupation and are having more farming experience also develop the habit of making new investments in the farm assets as and when funds become available to them. For this study, the farmers were classified into two groups, namely, farmers with experience of less than 10 years of farming and farmers who had more than 10 years of experience.

Table 9 shows the relationship between the experience in farming on the part of farmers and the levels of capital investment made by them.

From the Table 9 it has been revealed that out of 600 sample respondent farmers, 272 (45.33 per cent) had up to 10 years of farm experience and the remaining 328 farmers ( 54.67 per cent) had more than 10 years of farm experience. Out of 156 farmers who had reported a high level of investment, 100 (64.10 per cent) had more than 10 years of farm experience and 56 had farm experience upto 10 years in farming operations? In the case of farmers who had reported a medium level of investment, out of 316 farmers, 158 (50 per cent) had experience in agriculture for a period of upto 10 years and 158 (50 per cent) had more than 10 years of farm experience. Out of 128 farmers who had reported a low level of investment, 58 (45.31 per cent) had an experience of upto 10 years and the remaining 70 (54.69 per cent) had an experience of more than 10 years.

Here a null hypothesis was formulated that the experience in farming did not influence the level of capital investment and the two were independent variables. To test the null hypothesis, the chi-square test was applied and the results are presented in Table 10.

Table 10 reveals that the calculated chi-square value is greater than the table value at 5 per cent level of significance, and hence the hypothesis is rejected. It can be said that the level of capital investment is

\begin{tabular}{|l|c|c|c|c|}
\hline \multirow{2}{*}{ Experience in Farming } & \multicolumn{3}{|c|}{ Levels of Investment } & \multirow{2}{*}{ Total } \\
\cline { 2 - 5 } & High & Medium & Low & \\
\hline Up to 10 years & 56 & 158 & 58 & 272 \\
& $(35.90)$ & $(50)$ & $(45.31)$ & $(45.33)$ \\
\hline Above 10 years & 100 & 158 & 70 & 328 \\
& $(64.10)$ & $(50)$ & $(54.69)$ & $(54.67)$ \\
\hline Total & 156 & 316 & 128 & 600 \\
& $(100)$ & $(100)$ & $(100)$ & $(100)$ \\
\hline
\end{tabular}

Source: Primary data.

Figures in brackets represent percentage to total.

Table 9: Classification of sample farmers according to their experience in farming and their levels of capital investment.

\begin{tabular}{|l|l|l|l|l|l|}
\hline $\begin{array}{l}\text { Groups } \\
\text { Compared }\end{array}$ & $\begin{array}{l}\text { Calculated } \\
\text { Value }\end{array}$ & $\begin{array}{l}\text { Table } \\
\text { Value }\end{array}$ & $\begin{array}{l}\text { Degrees of } \\
\text { Freedom }\end{array}$ & $\begin{array}{l}\text { Level of } \\
\text { Significance }\end{array}$ & Inference \\
\hline $\begin{array}{l}\text { Experience of farming } \\
\text { and the } \\
\text { level of investment }\end{array}$ & 28.08 & 5.991 & 2 & 5 per cent & Significant \\
\hline
\end{tabular}

Table 10: Results of the chi-square test. 
dependent upon the experience of farming. Hence, it can be concluded that there is a relationship between experience in farming and the level of capital investment.

Use of the communication media and the level of capital investment: Communication media educated the farmers on various aspects of farming, such as the use of high yielding variety seeds, fertilizers, timely application of manures, use of pesticides, adoption of plant protection measures and effective farm management. The farmers, who use the media to acquire knowledge about farming operations, definitely get higher farm productivity and higher income which motivate them to invest more in the form of capital assets. Hence, the communication media is taken as a factor, which influences the level of capital investment.

The use of communication media by the sample farmers and their level of capital investment is presented in Table 11.

It is clearly evident from Table 11 that out of 600 sample farmers 37.33 per cent or 224 sample farmers had used the communication media, namely Television, Newspaper and the like and performed their agricultural activities and 62.67 per cent of 376 had not used the communication media for carrying out their agricultural operations. Out of 156 sample farmers who had reported a high level of investment, 38 (24.36 per cent) had used the communication media and the remaining 118 farmers (75.64 per cent) had not used the communication media. Out of the 316 sample farmers who had reported a medium level of investment, 174 (55.06 per cent) had not used the communication media and the remaining 142 (44.94 per cent) had used the communication media. In the case of farmers who had reported a low level of investment, out of 128 farmers, 84 (65.62 per cent) had not used the communication media and the remaining 44 farmers (34.38 per cent) had used the communication media.

A null hypothesis was formulated that the use of the communication media and the level of capital investment were two independent variables. To test the null hypothesis the chi-square test was applied and the results are presented in Table 12.

From the Table 12 it has been observed that the calculated Chisquare value is greater than the table value at 5 per cent level of significance and so the null hypothesis is rejected. It can be said that the level of capital investment is not dependent upon the use of communication media. Hence, it is found that there is a relationship

\begin{tabular}{|l|c|c|c|c|}
\hline \multirow{2}{*}{ Use of Communication Media } & \multicolumn{3}{|c|}{ Levels of Investment } & \multirow{2}{*}{ Total } \\
\cline { 2 - 4 } & High & Medium & Low & \\
\hline Used & 38 & 142 & 44 & 224 \\
& $(24.36)$ & $(44.94)$ & $(34.38)$ & $(37.33)$ \\
\hline Not Used & 118 & 174 & 84 & 376 \\
& $(75.64)$ & $(55.06)$ & $(65.62)$ & $(62.67)$ \\
\hline Total & 156 & 316 & 128 & 600 \\
& $(100)$ & $(100)$ & $(100)$ & $(100)$ \\
\hline
\end{tabular}

\section{Source: Primary data}

Table 11: Classification of sample farmers according to the use of communication media and the levels of capital investment.

\begin{tabular}{|l|l|l|l|l|l|}
\hline $\begin{array}{l}\text { Groups } \\
\text { Compared }\end{array}$ & $\begin{array}{l}\text { Calculated } \\
\text { Value }\end{array}$ & $\begin{array}{l}\text { Table } \\
\text { Value }\end{array}$ & $\begin{array}{l}\text { Degrees of } \\
\text { Freedom }\end{array}$ & $\begin{array}{l}\text { Level of } \\
\text { Significance }\end{array}$ & Inference \\
\hline $\begin{array}{l}\text { Use of } \\
\text { communication media } \\
\text { and the level of } \\
\text { investment }\end{array}$ & 19.30 & 5.991 & 2 & 5 per cent & Significant \\
\hline
\end{tabular}

Table 12: Results of the chi-square test.

\begin{tabular}{|l|c|c|c|c|}
\hline \multirow{2}{*}{ Training Camps Patrticipation } & \multicolumn{3}{|c|}{ Levels of Investment } & \multirow{2}{*}{ Total } \\
\cline { 2 - 5 } & High & Medium & Low & \\
\hline Participants & 30 & 86 & 40 & 186 \\
& $(19.23)$ & $(27.22)$ & $(31.25)$ & $(31.00)$ \\
\hline Non-participants & 126 & 230 & 88 & 414 \\
& $(80.77)$ & $(72.78)$ & $(68.75)$ & $(69.00)$ \\
\hline Total & 156 & 316 & 128 & 600 \\
& $(100)$ & $(100)$ & $(100)$ & $(100)$ \\
\hline
\end{tabular}

Source: Primary data

Figures in brackets represent percentage to total.

Table 13: Classification of sample farmers according to their participation in training camps and levels of capital investment.

\begin{tabular}{|l|l|l|l|l|l|}
\hline $\begin{array}{l}\text { Groups } \\
\text { Compared }\end{array}$ & $\begin{array}{l}\text { Calculated } \\
\text { Value }\end{array}$ & $\begin{array}{l}\text { Table } \\
\text { Value }\end{array}$ & $\begin{array}{l}\text { Degrees of } \\
\text { Freedom }\end{array}$ & $\begin{array}{l}\text { Level of } \\
\text { Significance }\end{array}$ & Inference \\
\hline $\begin{array}{l}\text { Participation in } \\
\text { training camps } \\
\text { and the level of } \\
\text { investment }\end{array}$ & 5.04 & 5.991 & 2 & 5 per cent & $\begin{array}{l}\text { Not } \\
\text { significant }\end{array}$ \\
\hline
\end{tabular}

Table 14: Results of the chi-square test.

between the use of communication media and the level of capital investment in agriculture, made by the sample farmers.

Participation in training camps and the level of capital investment: The training programmes for farmers are conducted mainly for the purpose of imparting knowledge about up to date and progressive farming practices. The farmers who participate in training programmes obtain information on the modern scientific devices and technologies and also on the effective and efficient utilisation of available farm resources. Generally, the training programmes are sponsored by agricultural departments, farmers' associations, agricultural colleges, universities and research centres. The participants are also taken to the model farms for field study and in the valedictory sessions of such training programmes, all the participants are given leaflets and pamphlets, which contain useful information to the farmers on farming techniques. Since the training programmes provide an insight into the new technologies and practices, it is taken as a factor influencing the level of capital investment in agriculture made by the farmers.

Table 13 presents the relationship between participation of the farmers in the training programmes and the level of capital investment made by them.

Table 13 shows that out of the total of 600 sample farmers, only 186 (31.00 per cent) had participated in training programmes and training camps and the remaining 414 (69.00 per cent) had not participated in any such training programmes. Out of 156 farmers, who had reported a high level of investment only 60 (19.23 per cent) had participated in training programmes and the remaining 126 (80.77 per cent) had not participated in training programmes. Out of 316 sample farmers who had reported a medium level of investment, only 86 (27.22 per cent) had participated in the training programmes and the remaining 230 farmers (72.78 per cent) had not participated in training programmes. Out of the 128 sample farmers who had made a low level of investment, 88 (68.75 per cent) had not participated in any training camps or programmes and only 40 farmers ( 31.25 per cent) had participated in training programmes.

A null hypothesis was formulated that the participation in training camps and the level of investment were two independent variables. To test the null hypothesis, the chi-square test was applied and the results are presented in Table 14. 
It is clearly evident from Table 14 that the calculated chi-square value is less than the table value at 5 per cent level of significance, and so the null hypothesis is accepted. It could be stated that the level of capital investment is not dependent upon the participation in training programmes or camps. Hence, there is found to be no relationship between participation in training programmes and the level of capital investment made in agriculture.

\section{Financial factors}

Financial factors were those factors that helped the farmers to incerase their earnings, which in their turn enabled the farmers to make capital investment in agriculture. The financial factors considered for the purpose of this study include possession of farmer's own farmlands, possession of irrigation wells, farming as a primary or as a secondary activity, income of the family members, bank loans, incentives offered and mechanization.

In this section, an attempt is made to analyse the relationship between the level of investment of farmers and the chosen financial factors. Each factor is tested to find out whether it had a significant influence on the level of capital investment. For testing the influence, the following seven null hypotheses have been framed.

a. Possession of one's own farmlands did not influence the level of capital investment.

b. Possession of one's own irrigation wells did not influence the level of capital investment.

c. Farming undertaken as a primary or secondary activity did not influence the level of capital investment.

d. Income of the family members did not influence the level of capital investment.

e. Utilization of bank loans did not influence the level of capital investment.

f. Utilization of incentives did not influence the level of capital investment, and

g. Mechanization did not influence the level of capital investment.

Possession of one's farm lands: Farmers undertake cultivation either on their own land or cultivate the lands of others as landless or tenant farmers by taking lands either on lease or on mortgage. Unlike the farmers who own their lands, the choice of cultivation of crops for the tenant farmers is limited, as they should vacate their farmlands after the prescribed period or harvest of crops. So, ownership of the farm lands is taken as a factor influencing the level of capital investment in agriculture.

Table 15 shows the ownership and possession of farmlands and the level of capital investment.

\begin{tabular}{|l|c|c|c|c|}
\hline \multirow{2}{*}{ Types of Farmers } & \multicolumn{3}{|c|}{ Levels of Investment } & \multirow{2}{*}{ Total } \\
\cline { 2 - 4 } & High & Medium & Low & \\
\hline Farmers with own lands & $\begin{array}{c}130 \\
(83.33)\end{array}$ & $\begin{array}{c}254 \\
(80.38)\end{array}$ & $\begin{array}{c}20 \\
(15.63)\end{array}$ & $\begin{array}{c}404 \\
(67.33)\end{array}$ \\
\hline Farmers without own land & 26 & 62 & 108 & 196 \\
& $(16.67)$ & $(19.62)$ & $(84.37)$ & $(32.67)$ \\
\hline Total & 156 & 316 & 128 & 600 \\
& $(100)$ & $(100)$ & $(100)$ & $(100)$ \\
\hline
\end{tabular}

\section{Source: Primary data}

Figures in brackets represent percentage to total.

Table 15: Classification of sample farmers according to ownership and possession of farm lands and the levels of capital investment.

\begin{tabular}{|l|l|l|l|l|l|}
\hline $\begin{array}{l}\text { Groups } \\
\text { Compared }\end{array}$ & $\begin{array}{l}\text { Calculated } \\
\text { Value }\end{array}$ & $\begin{array}{l}\text { Table } \\
\text { Value }\end{array}$ & $\begin{array}{l}\text { Degrees of } \\
\text { Freedom }\end{array}$ & $\begin{array}{l}\text { Level of } \\
\text { Significance }\end{array}$ & Inference \\
\hline $\begin{array}{l}\text { Possession of owned } \\
\text { farm lands and } \\
\text { the level of capital } \\
\text { investment }\end{array}$ & 196.62 & 5.991 & 2 & 5 per cent & Significant \\
\hline
\end{tabular}

Table 16: Results of the chi-square test.

\begin{tabular}{|l|c|c|c|c|}
\hline \multirow{2}{*}{ Types of Farmers } & \multicolumn{3}{|c|}{ Levels of Investment } & \multirow{2}{*}{ Total } \\
\cline { 2 - 4 } & High & Medium & Low & \\
\hline Possession of irrigation well & 124 & 222 & 38 & 344 \\
& $(79.49)$ & $(70.25)$ & $(29.69)$ & $(57.33)$ \\
\hline Non-possessing irrigation well & 32 & 94 & 90 & 256 \\
& $(20.51)$ & $(29.75)$ & $(70.31)$ & $(42.67)$ \\
\hline Total & 156 & 316 & 128 & 600 \\
& $(100)$ & $(100)$ & $(100)$ & $(100)$ \\
\hline
\end{tabular}

Source: Primary data

Figures in brackets represent percentage to total.

Table 17: Classification of sample farmers according to the ownership of irrigation wells and the levels of capital investment.

It has been inferred from Table 15 that out of the 600 sample farmers, 404 farmers (67.33 per cent) were found to have engaged themselves in agricultural operations on lands of their own and the remaining 196 farmers (32.67 per cent) farmers did not own lands but were engaged in agricultural operations. In the case of farmers who had reported a high level of investment, out of 156 sample farmers, 130 of them (83.33 per cent) had owned their lands. Out of 316 sample farmers who had reported a medium level of investment, 254 of them (80.38 per cent) had owned their lands and 62 of them (19.62 per cent) did not own their lands. Out of 128 farmers who had reported a low level of investment, 108 (84.37 per cent) were found to be farmers without ownership of lands and only 20 of them ( 15.63 per cent) had own lands.

A null hypothesis was formulated that the possession of one's own farm lands and the level of capital investment were two independent variables. To test the hypothesis the chi-square test was applied and the results are shown in Table 16.

It has been revealed from Table 16 that the calculated chi square value is greater than the table value at 5 per cent level of significance and so the null hypothesis was rejected. Therefore, the level of capital investment is found to depend on the possession of own farmlands by the farmers. Hence, there is a significant relationship between the level of capital investment and the possession of one's own farmlands.

Possession of irrigation wells: Irrigation forms an integral and essential part of sustained and successful agricultural operations. Possession of irrigation wells, the ownership of which may be full or partial, has a major role in influencing capital investment in agriculture. As the supply of water is not assured, many depend mostly on rainfall. The irrigation wells enable the farmers to have their own choice of crops without depending too much on the monsoons. The irrigation wells provide sufficient water for the rearing of livestock and poultry and growing of tree crops. Hence, the possession of irrigation wells is identified as yet another factor which influences the levels of capital investment in agriculture.

Table 17 presents the possession of own irrigation wells and the level of capital investment for the sample farms.

From Table 17 it has been observed that out of 600 sample farmers. 344 (57.33 per cent) had owned irrigation wells of their own and 256 
(42.67 per cent) did not own and possess irrigation wells. Out of 156 farmers who had reported a high-level of investment, 124 farmers (79.49 per cent) were in possession of their own irrigation wells and 32 farmers (20.51 per cent) did not own irrigation wells. Out of 316 farmers who had reported a medium level of investment, 222 (70.25 per cent) had own irrigation wells and 94 (29.75 per cent) did not. Further, it could be seen that out of 128 farmers who had reported a low-level of investment, only 38 (29.69 per cent) possessed irrigation wells and 90 (70.31 per cent) did not possess irrigation wells of their own.

A null hypothesis was formulated that the possession of irrigation wells and the level of capital investment were two independent variables. To test the null hypothesis and to test the relationship between the availability of irrigation wells and the level of capital investment the chi-square test was applied and the results are presented in Table 18.

It is clearly evident from Table 18 that the calculated chi-square value is greater than the table value at 5 per cent level of significance and so the null hypothesis is rejected. It could be said that the level of investment and the availability of irrigation wells are dependent variables. Hence there is found to be a close relationship between the level of capital investment and the ownership of irrigation wells.

Farming as a primary or secondary activity: The cultivating farmers can be classified into two categories namely; farmers engaged in farming as a primary occupation and those engaged in farming as a secondary occupation. The primary farmers depend upon the farm produce for most of their needs, such as food, clothing, shelter and education. The remaining surplus is utilised by them for capital investment. The secondary farmers are mostly the employees of either the government or the non-governmental organizations engaged in farming on a part-time basis. Hence, farming carried on as a primary or secondary occupation is considered as yet another factor influencing the level of capital investment in agriculture.

The category of farmers and their level of capital investment in agriculture is shown in Table 19.

Table 19 reveals that out of the total number of 600 sample farmers, 70.64 per cent of farmers were engaged in farming as their primary occupation and the remaining 29.33 per cent were engaged in farming as a secondary occupation. Out of 156 farmers who had reported a high-level investment, 122 (78.21 per cent) were farmers engaged in farming as primary occupation and 34 (21.79 per cent) were engaged in farming as secondary occupation. Out of 316 farmers who had

\begin{tabular}{|l|l|l|l|l|l|}
\hline $\begin{array}{l}\text { Groups } \\
\text { Compared }\end{array}$ & $\begin{array}{l}\text { Calculated } \\
\text { Value }\end{array}$ & $\begin{array}{l}\text { Table } \\
\text { Value }\end{array}$ & $\begin{array}{l}\text { Degrees of } \\
\text { Freedom }\end{array}$ & $\begin{array}{l}\text { Level of } \\
\text { Significance }\end{array}$ & Inference \\
\hline $\begin{array}{l}\text { Presence of irrigation } \\
\text { wells and the level of } \\
\text { capital investment }\end{array}$ & 92.60 & 5.991 & 2 & 5 per cent & Significant \\
\hline
\end{tabular}

Table 18: Results of the chi-square test

\begin{tabular}{|l|c|c|c|c|}
\hline \multirow{2}{*}{ Occupational Categories } & \multicolumn{3}{|c|}{ Levels of Investment } & \multirow{2}{*}{ Total } \\
\cline { 2 - 4 } & High & Medium & Low & \\
\hline Primary occupation & 122 & 204 & 98 & 424 \\
& $(78.21)$ & $(64.56)$ & $(76.56)$ & $(70.67)$ \\
\hline Secondary occupation & 34 & 112 & 30 & 176 \\
& $(21.79)$ & $(35.44)$ & $(23.44)$ & $(29.33)$ \\
\hline All farmers & 156 & 316 & 128 & 600 \\
& $(100)$ & $(100)$ & $(100)$ & $(100)$ \\
\hline
\end{tabular}

Source: Primary data.

Figures in brackets represent percentage to total.

Table 19: Occupational categories of farmers and their level of capital investment.

\begin{tabular}{|l|l|l|l|l|l|}
\hline $\begin{array}{l}\text { Groups } \\
\text { Compared }\end{array}$ & $\begin{array}{l}\text { Calculated } \\
\text { Value }\end{array}$ & $\begin{array}{l}\text { Table } \\
\text { Value }\end{array}$ & $\begin{array}{l}\text { Degrees of } \\
\text { Freedom }\end{array}$ & $\begin{array}{l}\text { Level of } \\
\text { Significance }\end{array}$ & Inference \\
\hline $\begin{array}{l}\text { Category of } \\
\text { farmers and level of } \\
\text { investment }\end{array}$ & 12.96 & 5.991 & 2 & 5 per cent & Significant \\
\hline
\end{tabular}

Table 20: Results of the chi-square test.

\begin{tabular}{|l|c|c|c|c|c|}
\hline \multirow{2}{*}{ Incomes of Family Members } & \multicolumn{3}{|c|}{ Levels of Investment } & \multirow{2}{*}{ Total } \\
\cline { 2 - 5 } & High & Medium & Low & \\
\hline Families having income from other members & 108 & 160 & 68 & 336 \\
& $(69.24)$ & $(50.63)$ & $(53.13)$ & $(56.0)$ \\
\hline Families not having income from other members & 48 & 156 & 60 & 264 \\
& $(30.76)$ & $(49.37)$ & $(46.87)$ & $(44.0)$ \\
\hline All families & 156 & 316 & 128 & 600 \\
& $(100)$ & $(100)$ & $(100)$ & $(100)$ \\
\hline
\end{tabular}

Source: Primary data

Figures in brackets represent percentage to total.

Table 21: Sample farmers having additional income from other family members and the level of capital investment.

reported a medium level of investment, 204 (64.56 per cent) were farmers engaged in farming as a primary occupation and $112(35.44$ per cent) were farmers engaged in farming as a secondary occupation. It could also be seen from Table 19 that out of 128 farmers who had reported a low level of investment, 98 (76.56 per cent) belonged to the category of primary farmers and 30 (23.44 per cent) belonged to the category of farmers carrying on farming as a secondary occupation.

A null hypothesis was formulated such as that the occupational category of the farmers and the level of their capital investment were two independent variables. To test this null hypothesis, and also to test the relationship between these two variables the chi-square test was used and the results are shown in Table 20.

Table 20 shows that the calculated chi-square value is greater than the table value at 5 per cent level of significance, and hence the null hypothesis is rejected. It is clear that there is a relationship between the category of farmers carrying on farming as a primary or as a secondary occupation and their level of capital investment.

Income of the family members: The total income of the family plays a significant role in capital investment in the farms. The family members comprise the farmers, their spouse, elder members and children, all living as members of one family. The financial capacity of a farmer, having a number of earning members in his family, would be better than that of a farmer whose family has mostly non-earning members. So, the total income of all the family members is taken as another factor influencing the level of capital investment in agriculture.

The relationship between families having additional income from other family members and their levels of capital investment is presented in Table 21.

It has been inferred from Table 21 that out of the total number of 600 farmers, 56.0 per cent belonged to the category of families having additional earners and the remaining 44.0 per cent belonged to the category of families not having additional earners. Out of 156 farmers who had reported a high-level investment, 108 (69.24 per cent) belonged to families with additional earners and 48 (30.76 per cent) belonged to families not having additional earners. Out of 316 farmers, who had reported a medium level investment, 160 (50.63 per cent) belonged to families having additional income and 156 (49.37 per cent) belonged to families not having additional income. Out of 128 farmers who had reported a low-level investment, 68 (53.13 per cent) belonged 
to families having additional earning members and 60 (46.87 per cent) belonged to families not having additional earning members.

Hence, a null hypothesis was formulated that additional income from other family members and the level of capital investment were two independent variables. By applying chi-square test, the relationship between additional incomes from other family members and the levels of capital investment was tested. The results of the chi-square test are presented in Table 22.

It is clearly evident from Table 22 that the calculated chi-square value was more than table value at the 5 per cent level of significance, and hence the null hypothesis is rejected. It is understood that the level of capital investment is very much dependent upon the incomes of other family members. Hence, a relationship is found to exist between the income from other family members and the level of capital investment.

Bank loans and the level of capital investment: Banks advance agricultural loans to the farmers at low rates of interest, and accept repayments from them in easy and convenient instalments, which help the farmers to make investments in their farms. So the utilization of bank loan facilities is taken as another factor influencing the level of capital investment made in agriculture by the farmers.

Table 23 shows the utilization of bank loans and the level of capital investment in agriculture.

It is clear from Table 23 that out of 600 sample families, 356 had utilised loans from banks and the remaining 244 families did not do so. Out of 156 families who had reported a high-level of investment, 112 (71.79 per cent) had utilised bank loans and 44 (28.21 per cent) had not utilised any bank loans. Out of 316 families who had reported a medium level of investment, 214 (67.72 per cent) had utilised bank loans and 102 (32.28 per cent) had not utilised loans from banks. Out of 128 families who had reported a low-level of investment, 30 (23.44 per cent) had utilized bank loans and 98 (76.56 per cent) families had not utilized the same.

A null hypothesis was formulated that the bank loans and the level of capital investment were two independent variables. To test the null

\begin{tabular}{|l|l|l|l|l|l|}
\hline $\begin{array}{l}\text { Groups } \\
\text { Compared }\end{array}$ & $\begin{array}{l}\text { Calculated } \\
\text { Value }\end{array}$ & $\begin{array}{l}\text { Table } \\
\text { Value }\end{array}$ & $\begin{array}{l}\text { Degrees of } \\
\text { Freedom }\end{array}$ & $\begin{array}{l}\text { Level of } \\
\text { Significance }\end{array}$ & Inference \\
\hline $\begin{array}{l}\text { Additional income of } \\
\text { family members and } \\
\text { capital investment }\end{array}$ & 14.20 & 5.991 & 2 & 5 per cent & Significant \\
\hline
\end{tabular}

Table 22: Results of the chi-square test.

\begin{tabular}{|l|c|c|c|c|}
\hline \multirow{2}{*}{ Bank Loans } & \multicolumn{3}{|c|}{ Levels of Investment } & \multirow{2}{*}{ Total } \\
\cline { 2 - 4 } & High & Medium & Low & \\
\hline Families which have reported utilization & 112 & 214 & 30 & 356 \\
& $(71.79)$ & $(67.72)$ & $(23.44)$ & $(59.33)$ \\
\hline Families which have reported & 44 & 102 & 98 & 244 \\
non-utilization & $(28.21)$ & $(32.28)$ & $(76.56)$ & $(40.67)$ \\
\hline All families & 156 & 316 & 128 & 600 \\
& $(100)$ & $(100)$ & $(100)$ & $(100)$ \\
\hline
\end{tabular}

Source: Primary data.

Figures in brackets represent percentage to total.

Table 23: Utilization of bank loans and the level of capital investment.

\begin{tabular}{|l|l|l|l|l|l|}
\hline $\begin{array}{l}\text { Groups } \\
\text { Compared }\end{array}$ & $\begin{array}{l}\text { Calculated } \\
\text { Value }\end{array}$ & $\begin{array}{l}\text { Table } \\
\text { Value }\end{array}$ & $\begin{array}{l}\text { Degrees of } \\
\text { Freedom }\end{array}$ & $\begin{array}{l}\text { Level of } \\
\text { Significance }\end{array}$ & Inference \\
\hline $\begin{array}{l}\text { Bank loans and levels } \\
\text { of capital investment }\end{array}$ & 123.76 & 5.991 & 2 & 5 per cent & Significant \\
\hline
\end{tabular}

Table 24: Results of the chi-square test.

\begin{tabular}{|l|c|c|c|c|}
\hline \multirow{2}{*}{ Incentives } & \multicolumn{3}{|c|}{ Levels of Investment } & \multirow{2}{*}{ Total } \\
\cline { 2 - 4 } & High & Medium & Low & \\
\hline Families reporting utilization & 92 & 124 & 48 & 264 \\
& $(58.97)$ & $(39.24)$ & $(37.5)$ & $(44.0)$ \\
\hline Families reporting non-utilization & 64 & 192 & 80 & 336 \\
& $(41.03)$ & $(60.76)$ & $(62.5)$ & $(56.0)$ \\
\hline All families & 156 & 316 & 128 & 600 \\
& $(100)$ & $(100)$ & $(100)$ & $(100)$ \\
\hline
\end{tabular}

Source: Primary data.

Figures in brackets represent percentage to total.

Table 25: Incentives and the level of capital investment.

\begin{tabular}{|l|l|l|l|l|l|}
\hline $\begin{array}{l}\text { Groups } \\
\text { Compared }\end{array}$ & $\begin{array}{l}\text { Calculated } \\
\text { Value }\end{array}$ & $\begin{array}{l}\text { Table } \\
\text { Value }\end{array}$ & $\begin{array}{l}\text { Degrees of } \\
\text { Freedom }\end{array}$ & $\begin{array}{l}\text { Level of } \\
\text { Significance }\end{array}$ & Inference \\
\hline $\begin{array}{l}\text { Incentives and levels } \\
\text { of capital investment }\end{array}$ & 28.80 & 5.991 & 2 & 5 per cent & Significant \\
\hline
\end{tabular}

Table 26: Results of the chi-square test.

hypothesis, the chi-square test was applied. The results of the chisquare test are furnished in Table 24 .

Table 24 reveals that the calculated value is greater than the table value. Hence, the bank loans and the level of capital investment are found to be dependent variables and hence, the null hypothesis is rejected. The level of capital investment is found to be very much dependent upon the utilisation of bank loans.

Incentives and the level of capital investment: Incentives in various forms, such as subsidies on loans, insurance cover for farm assets, free power supply for irrigation pump sets, liberal farm loans, compensation for the loss of some of the farm assets, marketing and information facilities are provided by the government to enable the farmers to make use of these incentives for increasing their income. The farmers utilizing these incentives tend to make a higher level of capital investment than those who did not. Hence, incentives offered by the government are taken as another factor, which influences the level of capital investment in agriculture.

The utilisation of incentives and the level of capital investment in agriculture are presented in Table 25 .

From Table 25 it has been observed that, out of 600 sample farmers, 264 families (44.00 per cent) had utilised the various incentives offered by way of subsidies and 336 families ( 56.00 per cent) had not utilised the incentives offered by the government in any form. Out of 156 families who had reported a high-level of investment, 92 (58.97 per cent) had utilised the incentives offered and 64 (41.03 per cent) did not do so. Out of 316 families who had reported a medium level of investment, 124 families (39.24 per cent) had made use of incentives in the form of subsidies and 192 families (60.76 per cent) did not do so. It is clear that out of 128 families, who had reported a low level of investment, 48 families (37.5 per cent) had utilised the incentives and 80 families (62.5 per cent) did not do so.

A null hypothesis was formulated that the incentives and the level of capital investment were two independent variables. To test the relationship between two variables, the chi-square test was applied and the results are presented in Table 26.

It is clearly evident from Table 26 that the calculated chi-square value is more than table value at 5 per cent level, and hence the null hypothesis is rejected. Hence it is found that there is a close relationship between the utilisation of various incentives and the level of capital investment. 


\begin{tabular}{|l|c|c|c|c|}
\hline \multirow{2}{*}{ Mechanization } & \multicolumn{3}{|c|}{ Levels of Investment } & \multirow{2}{*}{ Total } \\
\cline { 2 - 5 } & High & Medium & Low & \\
\hline Adoption (number of families) & 118 & 128 & 30 & 276 \\
& $(75.64)$ & $(40.51)$ & $(23.44)$ & $(46.00)$ \\
\hline Non-adoption (number of families) & 38 & 188 & 98 & 324 \\
& $(24.36)$ & $(59.49)$ & $(76.56)$ & $(54.00)$ \\
\hline Total number of families & 156 & 316 & 128 & 600 \\
& $(100)$ & $(100)$ & $(100)$ & $(100)$ \\
\hline
\end{tabular}

Source: Primary data.

Figures in brackets represent percentage to total.

Table 27: Mechanization and the level of capital investment.

\begin{tabular}{|l|l|l|l|l|l|}
\hline $\begin{array}{l}\text { Groups } \\
\text { Compared }\end{array}$ & $\begin{array}{l}\text { Calculated } \\
\text { Value }\end{array}$ & $\begin{array}{l}\text { Table } \\
\text { Value }\end{array}$ & $\begin{array}{l}\text { Degrees of } \\
\text { Freedom }\end{array}$ & $\begin{array}{l}\text { Level of } \\
\text { Significance }\end{array}$ & Inference \\
\hline $\begin{array}{l}\text { Mechanization and } \\
\text { levels of capital } \\
\text { investment }\end{array}$ & 83.40 & 5.991 & 2 & 5 per cent & Significant \\
\hline
\end{tabular}

Table 28: Results of the chi-square test.

Mechanization and the level of capital investment: Mechanization increases productivity of the farm. Machines are used by farmers for ploughing, leveling, spraying pesticides, harvesting, irrigation, application of fertilizers and production and hence mechanization is taken as an important factor influencing the level of capital investment in agriculture.

The relationship between mechanization and the level of capital investment in agriculture is presented in Table 27.

Table 27 reveals that out of 600 sample families 276 of them $(46.00$ per cent) had chosen to use machines in agriculture and the remaining 324 of them (54.00 per cent) did not do so. Out of 156 families who had reported a high level of investment, 118 of them (75.64 per cent) had used modern machines and the remaining 38 families ( 24.36 per cent) did not do so. Out of 316 families which had reported a medium level of investment, 128 (40.51 per cent) had used machines for their farm activities and the remaining 188 families (59.49 per cent) did not do so. Out of 128 families who had reported a low level investment, only 30 (23.44 per cent) had chosen to use the machines for their agricultural operations and others did not do so.

A null hypothesis was formulated that the mechanization and the level of investment were two independent variables. To test the null hypothesis the chi-square test was applied and the results are provided in Table 28.

From Table 28 it has been revealed that the calculated chi-square value is greater than the table value at 5 per cent level of significance and hence the null hypothesis is rejected. It is clear that the level of capital investment is dependent upon the use and adoption of machines. Hence, there is found to exist a close relationship between mechanization and level of capital investment in agriculture [16].

\section{Findings}

The number of farmers and the level of capital investment made by them are found to be more in the case of those who had reported a medium level of investment, followed by the number of farmers who had reported a low level of investment and those who had reported a high level of investment.

The personal factors influencing the level of capital investment in agriculture, namely, educational qualifications and the size of family had a role to play in establishing the level of capital investment in agriculture. The other personal factors of farmers such as their experience in farming, use of communication media and their participation in training programmes had also a lot to do with the level of capital investment.

This analysis has proved that the financial factors, such as the possession and ownership of farm lands, possession and ownership of irrigation wells, income from other family members, bank loans, incentives offered by various government agencies and mechanization had significantly influenced the level of capital investment in agriculture. Carrying on farming operations as a primary or secondary professional activity had no significant influence on the level of capital investment.

\section{Suggestions}

a) Agriculture in India, viewed as a way of life, was not considered a productive proposition by the socially, economically and technologically backward population. The inter-sectoral mobility of personnel, resources and technology was very limited and it had created a vicious circle of technological isolation in the agricultural sector.

b) It is suggested that there should be an increase in the levels of investment made by the farm households engaged in the agricultural sector and more particularly by the small farmers.

c) It is suggested that steps should be taken to enhance the rate of public sector investment in the agricultural sector, which in its turn will motivate a higher level of private sector investment.

d) It is suggested that farmers training camps and training programmes may be conducted at the village level, periodically or at regular intervals of time.

e) Fixing appropriate due dates in relation to crop calendar ensuring timely disbursement and recovery of loans is advisable.

f) It is earnestly felt that the findings arrived at, and the valid suggestions made, in the wake of intensive study of agricultural credit with reference to commercial banks in Tamil Nadu carried out by the present writer will go a long way in enhancing the socio-economic level of farmers not only in the study area but all also over the entire country.

\section{References}

1. Agarwal AN, Kundanlal (1990) Rural Economy of India. Vikas Publishing House Pvt. Ltd., New Delhi, India.

2. Hill B, Ray D (1987) Economics of Agriculture, Food, Farming and Rural Economy. Prentice Hall of India.

3. Desai (1981) A Study of Rural Economics and Credit. Ashish Publishing House, New Delhi, India.

4. Dhawan BD (1998) Studies in Agricultural Investments and Rural Savings Common Wealth Publishers, New Delhi, India.

5. Hopkin JA, Barry PG, Baker CB (1973) Financial Management in Agriculture The Interstate Printer and Publisher, Inc., New York, USA.

6. Madani GMK (1988) Introduction to Econometrics, Principles and Applications Oxford and IBH Publishing Co. Pvt. Ltd., New Delhi, India.

7. Mathur BS (1990) Co-operative in India: critical analysis of the co-operative movement in India's planned economy. Shaitya Bhavan, Agra, India.

8. Mellor JW (1967) The Economics of Agricultural Development. Journal of Farm Economics 49: 533-535. 
Citation: Selvaraj N, Balajikumar P (2015) The Role of Commercial Banks in Providing Agricultural Credit in Tamil Nadu (Extent and Factors Influencing Investment) - India: A View. Bus Eco J 6: 158. doi:10.4172/2151-6219.1000158

9. Memoria CP (1979) Agricultural Problems of India, Kitab Mahal, AlahabadDelhi, India.

10. Misra SK, Puri VK (2001) Indian Economy, Himalaya Publishing House, Mumbai, India.

11. Rao, Hanumantha CH (1994) Agricultural Growth, Rural Poverty and Environmental Degradation in India, Oxford University Press, New Delhi, India.

12. Agarwal ML, Kumawat RK (1974) Potentialities of Increasing Farm Income through credit and new Technology. Agricultural Situation in India 28.

13. Alhavale MS, Yadav KS, Mishra JP (1971) Green Revolution and Short Term
Co-operative Credit-A Study in Two Districts of Madhya Pradesh. Indian Journal of Agricultural Economics 26.

14. Anderson JR, Joblhs NS (1973) Cobb-Douglas and Related Myths. Economic and Political Weekly, Review of Agriculture.

15. Nambbodri NV (1996) Capital Formation in Agriculture: Role of Institutional Finance and Government Investments. Indian Journal of Agricultural Economics 51.

16. Natarajann B (1977) Agricultural Credit and Banking. Tamil Nadu Journal of Co-operation 68. 